\title{
Mapping the spatial and temporal variation of agricultural and meteorological drought using geospatial techniques, Ethiopia
}

\author{
Abebe Senamaw', Solomon Addisu ${ }^{*}$ and K. V. Suryabhagavan²
}

\begin{abstract}
Background: Geographic Information System (GIS) and Remote Sensing play an important role for near real time monitoring of drought condition over large areas. The aim of this study was to assess spatial and temporal variation of agricultural and meteorological drought using temporal image of eMODIS NDVI based vegetation condition index (VCI) and standard precipitation index (SPI) from the year 2000 to 2016. To validate the strength of drought indices correlation analysis was made between $\mathrm{VCl}$ and crop yield anomaly as well as standardized precipitation index (SPI) and crop yield anomaly.

Results: The results revealed that the year 2009 and 2015 was drought years while the 2001 and 2007 were wet years. There was also a good correlation between NDVI and rainfall ( $r=0.71), \mathrm{VCl}$ and crop yield anomaly $(0.72)$, SPI and crop yield anomaly (0.74). Frequency of metrological and agricultural drought was compiled by using historical drought intensity map. The result shows that there was complex and local scale variation in frequency of drought events in the study period. There was also no year without drought in many parts of the study area. Combined drought risk map also showed that $8 \%, 56 \%$ and $35 \%$ of the study area were vulnerable to very severe, severe and moderate drought condition respectively.
\end{abstract}

Conclusions: In conclusion, the study area is highly vulnerable to agricultural and meteorological drought. There was also no year without drought in many parts of the study area. Thus besides mapping drought vulnerable areas, integrating socio-economic data for better understand other vulnerable factors were recommended.

Keywords: Drought, eMODIS NDVI, Geographic information system, Remote sensing, Standardized precipitation index, Waghimra zone

\section{Background}

Drought is one of the highest natural disasters globally (Maybank et al. 1995; Wilhite and Buchanan-Smith 2005; Morid et al. 2006; Paulo et al. 2012). The events are often associated with severe economic losses, reduction in growth domestic product (GDP) growth, crop failure and impact livestock rearing and mortality (FAO 2006; Hassan 2008; Ding et al.2011; Araya and Stroosnijder 2011;

\footnotetext{
*Correspondence: soladd2000@yahoo.com; salnew2000@gmail.com 1 College of Agriculture and Environmental Sciences, Bahir Dar University, P.o.box 5501 Bahir Dar, Ethiopia

Full list of author information is available at the end of the article
}

Zwane 2019). In addition to these, drought is a period of abnormally dry weather sufficiently prolonged because of a lack of precipitation that causes a serious hydrological imbalance and has connotations of a moisture deficiency with respect to water use requirements (Gordon et al. 1992; Van Loon 2015; Van Loon and Laaha 2015).The deficiencies have impact on both surface and groundwater resources and lead to reductions in water supply and quality, reduced agricultural productivity, diminished hydro-electric power generation, disturbed riparian and wetland habitats and reduced opportunities for some recreation activities (Wilhite et al. 2007; Misra 2014; 
Taylor et al. 2013; Turral et al. 2011; Wheeler and Von Braun 2013).

Drought is one of the most frequent climate-related disasters occurring across large portions of the African continent, often with devastating consequences for the food security of agricultural households (Rojas et al. 2011; Wilhite et al. 2014; Tadesse 2018). The effects of droughts are severe particularly in East African countries due to high rainfall variability in space and time (Pulwarty and Sivakumar 2014; Bayissa et al. 2017; Ahmadalipour and Moradkhani 2018; Liu et al. 2018; Meza et al. 2020). East Africa is highly vulnerable to the impact of frequent droughts and flood exacerbating the existing challenges to satisfy the food demands of an increasing population and improve the population's livelihood (Tadesse et al. 2014; Kalantari et al. 2018; Moges and Gebregiorgis 2013). A catastrophic drought occurred in the region in 1984, which killed an estimated 450,000 people in Ethiopia and Sudan (El Kenawy et al. 2016). More recently, a severe drought in Somalia and Southern Ethiopia in June 2011 resulted in more than 10 million people seeking humanitarian aid, as well as 380,000 refugees impacting neighboring countries (Vicente-Serrano et al. 2012). Among these countries, Ethiopia encounters frequent droughts (occurring once in every 2-3 years). Recently, severe drought events have occurred in Ethiopia in 2011, 2012, 2014 and 2015, with most of them covering the whole country (Edossa et al. 2010; Viste et al. 2013). In line with these Gebrehiwot et al. (2011) reported that Ethiopia, a highly populated country whose economy largely depends on rain-fed agriculture, drought is a recurrent climate phenomenon, with a frequency of occurrence approaching one event per decade.

There is ineffectiveness of current drought management practice which is a great concern worldwide that is largely crisis management (Wilhite et al. 2014). Drought characterization at regional and local scales has significant implications for drought management such as early warning system (Belal et al. 2014; Shahid and Behrawan 2008; Trenberth et al. 2014; Tsakiris et al. 2007; George Tsakiris 2017; Zarafshani et al. 2016). Thus far, few drought studies have been conducted on drought management using the historic time series of hydro-meteorological variables at a local level (e.g. zones or basins) in Ethiopia (Edossa et al. 2010; Legesse and Suryabhagavan 2014; Bayissa et al. 2017; Gebrehiwot et al.2011; Mohammed et al. 2018; Mekonen et al. 2020). More specific studies need to be conducted to better describe and characterize drought and to associate its characteristics with temporal and spatial variability of rainfall at a local level (e.g. at sub basin level).

In Ethiopia in general and study area in particular the livelihood of community is mainly depends on rain-feed agriculture. However, drought and crop failure are the common problem in which agriculture provides minimum food requirement for rapidly growing population. Metrological condition seriously and easily affect agricultural sector (Guo et al. 2016; Jayanthi et al. 2013). To reduce its possible consequences it is important to identify the extent of the areas prone to severe drought conditions and its frequency. Better analysis of drought allows for the development and implementation of successful polices to understand climate change impacts, improve food security and strengthen climate resilient (Liou and Mulualem 2019).

There is a firm conviction that the use of Satellite Remote Sensing data and Geographical Information System (GIS) can effectively facilitate the detection, identification and mapping of drought risk prone areas. Research reports attest that, specially, the use of modern Geo-spatial technology of Remote Sensing (RS) combined with Geographic Information System (GIS), for instance, affords powerful mechanisms, not only to monitor local natural events but also to obtain essential quantitative information at large spatial coverage and frequent temporal intervals (Prenzel 2004).

\section{Materials and methods Description of study area}

This study was conducted in Waghimra Zone Easter part of Amhara National Regional state, Ethiopia. It is located $435 \mathrm{~km}$ far from Bahir Dar, and $720 \mathrm{~km}$ from Addis Ababa. Geographically Waghimra Zone is located between $12^{\circ} 15^{\prime}$ and $13^{\circ} 16^{\prime} \mathrm{N}$ latitude and $38^{\circ} 20^{\prime}$ and $39^{\circ} 17^{\prime} \mathrm{E}$ longitude (Fig. 1). The most common features of the zone are its rugged topography characterized by mountains, steep escarpments and deeply incised valleys (Berhanu 2015). It has a mean annual rainfall of 150 to $700 \mathrm{~mm}$ in which the highest rainfall occur during summer season which starts in mid-June and ends in early September. The rainfall pattern in the area is relatively erratic and unpredictable.

\section{Data source and methods of data collection}

For this study an expedited MODIS (eMODIS) NDVI Terra image at $250 \mathrm{~m}$ spatial resolution were used to monitor vegetation condition. Since this study aims to assess agricultural drought data for crop growing season months from June to September for the 17 years period (2000 to 2016) were downloaded from (https://earth explorer.usgs.gov website). Enhanced/expedited/expandable MODIS (eMODIS) data provides separate Geostationary Earth Orbit Tagged Image File Format (GeoTIFF) for each product in a 10 day interval, allowing the users to download only the files they need. For example, the 


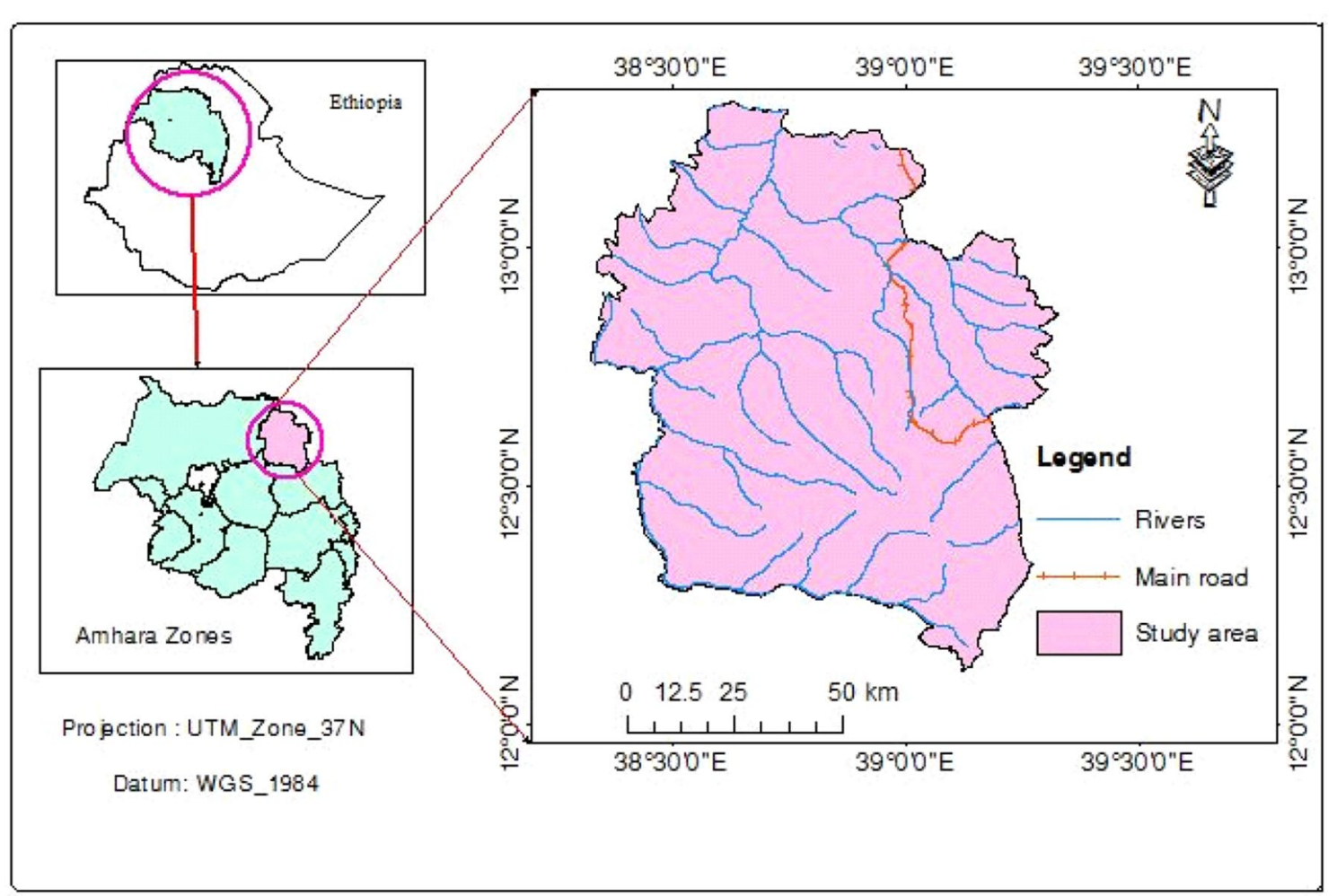

Fig. 1 Location map of the study area

eMODIS NDVI imagery for the month of June 2015 includes NDVI data from June 1st-10th, 6th-15th, 11th20th, 16th-25th, 21st-30th, and 26th-July 5th (Zhumanova et al. 2018). In this study 21 st to 30 th day interval of eMODIS NDVI imagery were taken for analysis purpose for the growing season of crops.

Monthly rainfall data recorded for 17 years were collected from Ethiopian National Meteorological Service Agency. Rainfall data was used to analyze relation between NDVI with variability of rainfall to drive standard precipitation index (SPI). In addition seasonal rainfall map was prepared from latitude/longitude files of those stations (Table 1 and Fig. 2). To validate rainfall and satellite derived indices agricultural production yield data was collected from Waghimra Zone Agricultural office from the period 2000 to 2016 .

\section{Data processing and analysis}

One weekly or 10 day's composite eMODIS data sets include NDVI, quality, acquisition image, and acquisition table and metadata files. In this study, NDVI and quality data has been used to calculate NDVI metrics. Quality files have been used to get the reliability of eMODIS NDVI image product which is computed in ArcGIS 10.5 spatial analysis tool (Eq. 1).
Table 1 List of weather stations and their geographic coordinate

\begin{tabular}{llll}
\hline No. & Station Name & Easting & Northing \\
\hline 1 & Tsiketema & 38.80 & 12.78 \\
2 & Amdework & 38.71 & 12.43 \\
3 & Asketema & 39.02 & 12.41 \\
4 & Chilla & 38.84 & 12.41 \\
5 & Kewazba & 38.92 & 12.48 \\
6 & Lugmura & 39.16 & 12.40 \\
7 & Sekota & 39.03 & 12.63 \\
8 & Yechila & 38.99 & 13.28 \\
9 & Tekeza Hydro power & 38.77 & 13.36 \\
10 & Wedisemro & 39.34 & 12.76 \\
11 & Lalibela & 39.04 & 12.04 \\
12 & Guhala & 38.05 & 12.24 \\
13 & Chenek/Semen terra & 38.18 & 13.27 \\
14 & Kobbo & 39.63 & 12.33 \\
\hline
\end{tabular}

Reliable NDVI $=(\mathrm{QC}==0) *(\mathrm{NDVI}>2000) * \mathrm{NDVI}$

where, reliable NDVI = reliable NDVI image which have values range from 0 to $10,000, \mathrm{QC}=$ quality image which 


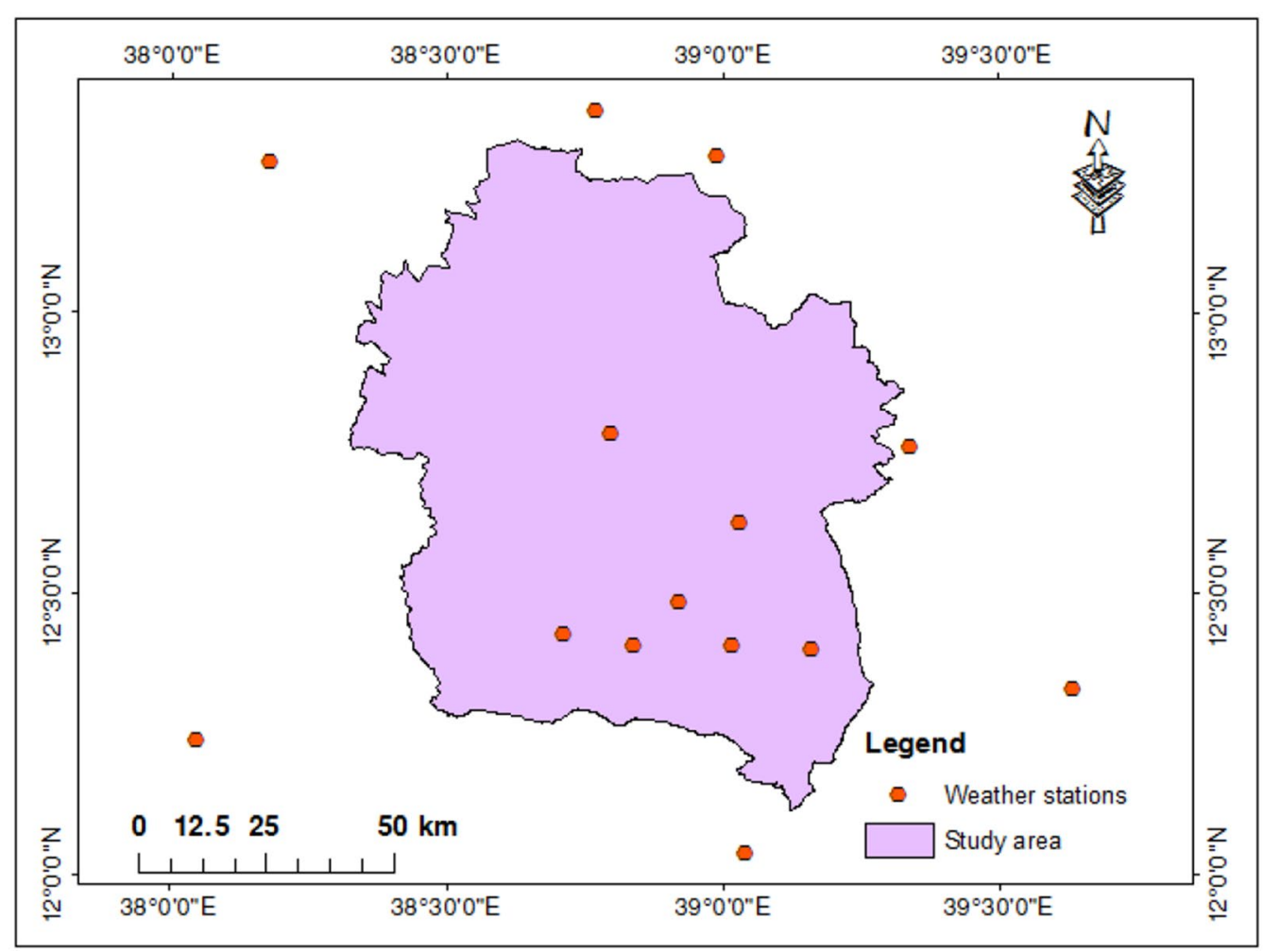

Fig. 2 Location of weather station in Waghimra Zone Ethiopia

have values from 0 to 10 where 0 is good values and 10 is fill values, NDVI is image which have values ranges from -2000 to 10,000 where -2000 is fill values and -1999 to 10,000 is valid range. After applying scale factor (the scale factor is 0.0001) NDVI values range from -0.2 to1.0 where valid/normal valid or normal NDVI ranges from 0.0 to 0.1 (Zhu et al. 2013) (Eq. 2).

$$
\text { NormalNDVI }=\text { Reliable NDVI } * 0.0001
$$

Time series NDVI variation was derived from the calculation of NDVI using the eMODIS NDVI data set for the year 2000 to 2016 and also used to generate the maximum, minimum and average NDVI values of each season for the year 2000 to 2016 using ArcGIS 10.5 environment spatial analysis tool. Based on the threshold value Vegetation Condition Index was computed. To determine average value of monthly and seasonal composites of NDVI values, float (math) and cell statistics toolset of ArcGIS 10.5 were applied.

\section{Vegetation condition index (VCl)}

Normalize Different Vegetation Index (NDVI) has been extensively used in the past for vegetation monitoring; it is often very difficult to interpret in relation to vegetation condition, especially when comparing different ecosystems. The vegetation condition index reflects the overall effect of rainfall, soil moisture, weather and agricultural practices (Kogan 1995). To compare the current NDVI with historical Vegetation Condition Index was used (Liu and Kogan 1996). Accordingly in areas like Waghimra which have different ecosystems and non-homogenous topography VCI is important for one to compare the weather impact in areas with different ecological and economical resources, since the index captures rainfall dynamics better than the NDVI particularly in geographically non homogeneous areas.

The VCI has been used to estimate the climate impact on vegetation. This index is most useful during the growing season because it is a measure of vegetation vigor. When the vegetation is dormant (not in the summer season), the VCI cannot be used to measure moisture stress or drought. In different parts of the world Vegetation Condition Index has been extensively used to monitor vegetation conditions (Bhuiyan et al. 2006; Winkler et al. 2017; Demisse et al. 2018; Tadesse et al. 2014). Anything that stresses the vegetation including insects, disease, 
and lack of nutrients will result in decreases in plant growth and therefore lower VCI values. Also, areas that have significant irrigation may not respond to precipitation deficiencies (Quiring and Papakryiakou 2003). As shown in Eq. (3) Vegetation condition index normalize NDVI on pixel by pixel basis scaling between the maximum and minimum value of NDVI (Liou and Mulualem 2019). For each monthly and seasonal NDVI image, VCI will be processed from 2000 to 2016 using the ArcGIS raster calculator (Eq. 3).

$$
\mathrm{VCI} j=\frac{(\mathrm{NDVIj}-\mathrm{NDVImin}) * 100}{\text { NDVImax }- \text { NDVImin }}
$$

where, NDVImax and NDVImin are calculated from the long-term record for that month, and $j$ is the index of the current month in ArcGIS cell statistics. VCI value is being measured in percentage ranging from 1 to 100 reflecting change in vegetation condition from extremely low to high VCI (Liu and Kogan 1996). The VCI values between 50 and $100 \%$ indicates slight or optimal/normal conditions whereas VCI values close to zero percent reflects an extreme dry season (Thenkabail et al 2004). The VCI was reclassified into five clusters (Table 2).

\section{Standardized precipitation index (SPI)}

Standard precipitation index, developed by Mckee et al. (1993) is the most widely used index for calibrating the magnitude and duration of drought events. SPI is used to examine the severity and spatial patterns of drought distribution in a given region (Guttman 1998 and Wattanakij et al. 2006). Guttman (1998) has made comparison of Palmers Drought Severity Index (PDSI) and SPI, and recommend SPI as drought index, as it is easy to determine and has greater spatial consistence. It has been used in many studies to determine the frequency of precipitation distribution like the effect of the time scales on the drought parameters, and the spatial classification of drought patterns (Edossa et al. 2010; Hayes et al. 2011; Gebrehiwot et al. 2011; Mohammed et al. 2018). In this study the SPI values at two time-scales, (three

Table 2 Classification of $\mathrm{VCl}$ values in terms of drought

\begin{tabular}{ll}
\hline VCl value (\%) & Category \\
\hline 0 to 20 & Very severe drought \\
21 to 35 & Severe drought \\
36 to 50 & Moderate drought \\
51 to 60 & Slight drought \\
61 and above & Optimum/normal \\
\hline
\end{tabular}

months SPI-3) was computed. Seasonal rainfall data have been used as an input to compute the SPI for the periods 2000-2016. Spatial distribution of meteorological drought was prepared from latitude/longitude files of those stations (Table 1 and Fig. 2).

The software which automatically calculates SPI value by using observed monthly rainfall data to detect historical drought at 1, 3, 6, 9, 12, 36 and 48 months 'time scale. It is freely available at (https://drought.unl.edu/droug htmonitoring/SPI/SPI Program.aspx) website.

Mathematically SPI is calculated based on following empirical formula (Eq. 4)

$$
\mathrm{SPI}=\{(\mathrm{Xij}-\mathrm{Xim}) / \sigma\}
$$

where, $(X i j=$ is the seasonal precipitation and, $X i m$ is its long-term seasonal mean and $\sigma$ is its standard deviation). SPI results computed from seasonal rainfall data were assigned to each grid cell of the study area and reclassified based on drought severity classes (Table 3 ). Positive SPI values indicate the rainfall is greater than median rainfall and negative values indicate less than median rainfall. SPI values of meteorological stations have been spatially interpolated using inverse distance weight of ArcGIS spatial analysis tool box to create drought severity map of study area at multiple time scale.

\section{Drought frequency analysis}

In this study the seasonal frequency maps derived from agricultural and metrological drought indices were reclassified into common scale based on the frequency of drought occurrence. To generate drought frequency map, each drought indices have been reclassified in to binary images for each of the drought severity class. Those maps are added to obtain the frequency of slight, moderate, severe and very severe drought occurrence at each pixel level for both agricultural and meteorological drought. The resultant severity maps were then added to get agricultural and meteorological drought risk maps. The probability of drought occurrence in a given area can be classified into high, moderate and low drought

Table 3 Metrological drought risks classification using SPI value (McKee et al. 1993)

\begin{tabular}{ll}
\hline SPI values & Drought category \\
\hline$<-2.00$ and less & Extreme drought \\
-1.50 to -1.99 & Severe drought \\
-1.00 to -1.49 & Moderate drought \\
0 to -0.99 Near & Normal or mild drought \\
Above 0 & No drought \\
\hline
\end{tabular}


probability zones when drought occurs in more than $50 \%, 30$ to $50 \%$ and less than $30 \%$ of the years, respectively (Lemma 1996). Based on these criteria, the frequency maps of each drought classes are reclassified into five classes based on the frequency of drought occurrence in study periods: $0-2$ classified as no drought; $3-4$ as slight drought; $5-8$ as moderate drought; $9-13$ as severe drought; $13-16$ as very severe drought. Finally, maps from agricultural and meteorological drought frequency maps were weighted according to the percentage of influence, and then combined using weighted overly analysis (Fig. 3).

\section{Results and discussions}

Relationship between seasonal rainfall and normalized vegetation index (NDVI)

The results of rainfall and vegetation condition revealed that there is a good correlation $(r=0.71)$ between rainfall and NDVI (Fig. 4). This indicates that it is possible to generalize that in all the 17 years $51 \%$ of NDVI variability can be explained by seasonal rainfall. Whereas, a study conducted in East Shewa Zone by Legesse and Suryabhagavan (2014) for the period between 1996 and 2008 has reported that $42 \%$ of NDVI variability was explained by
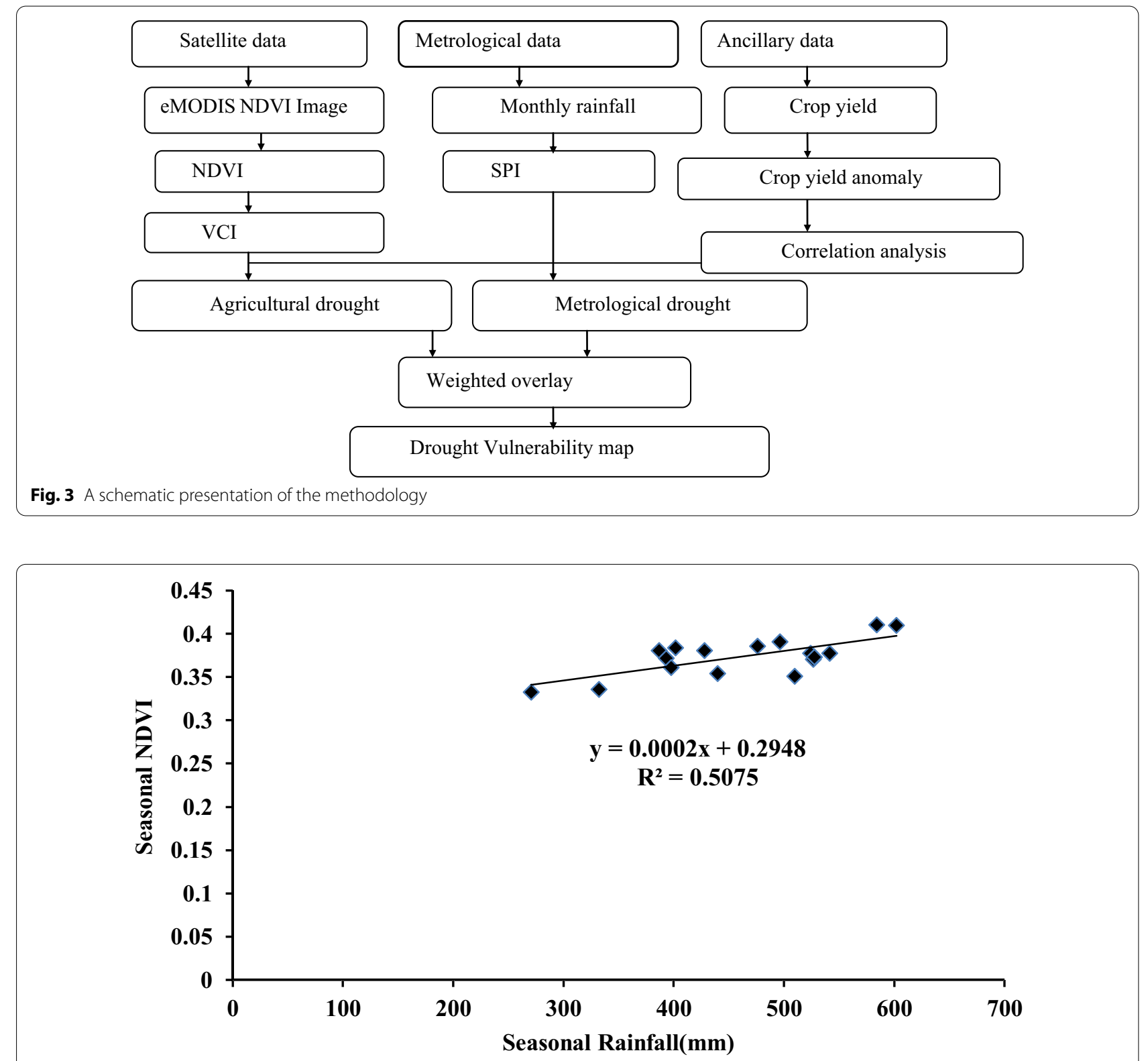

Fig. 4 Seasonal (June to September) pattern of rainfall and NDVI (2000 to 2016) 


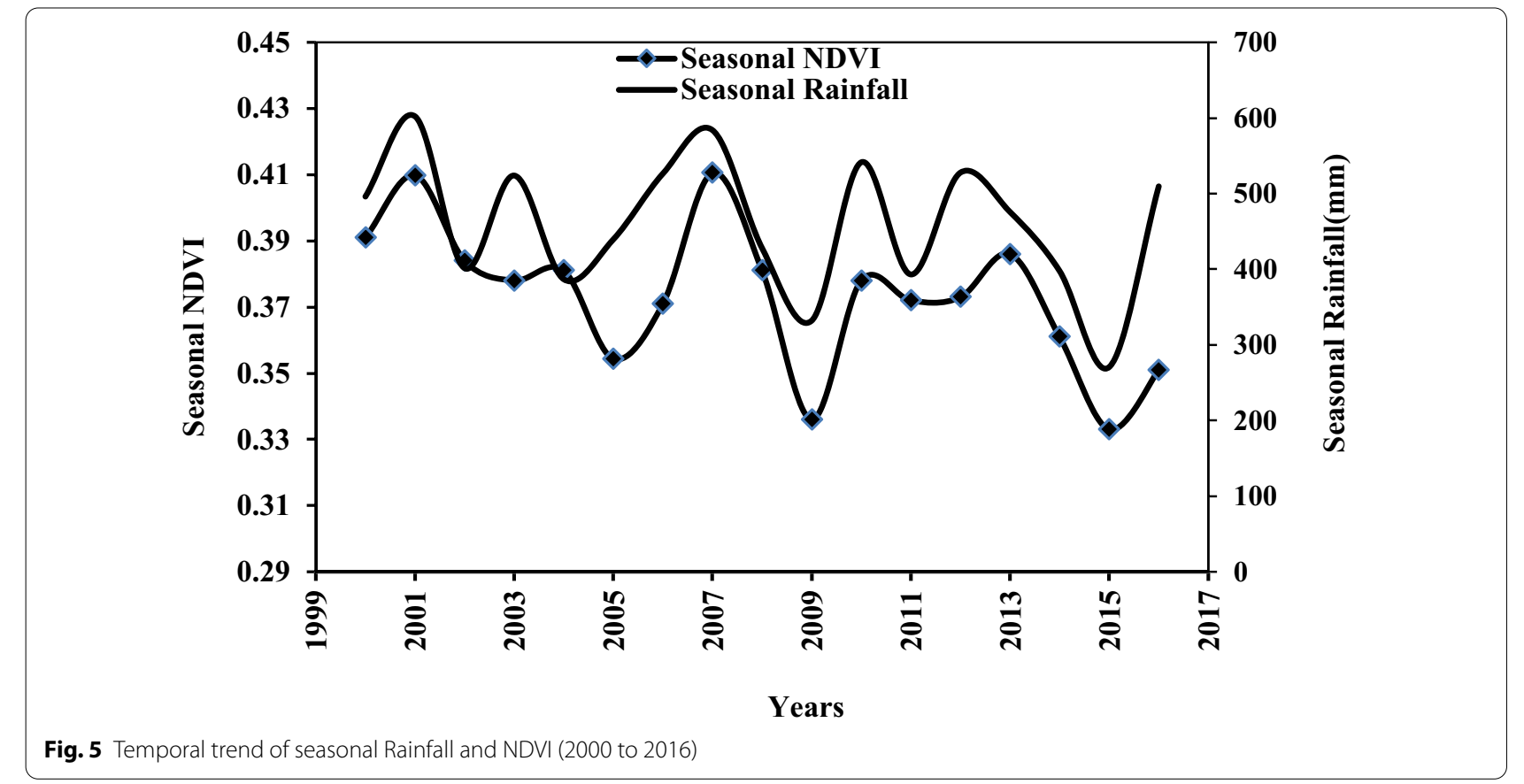
700

seasonal rainfall. Highly rainfall dependent country 's like Ethiopia the amount and distribution of rainfall during cropping season are more critical and determinates (Tesfaye and Walker 2004). From the period 2000 to 2016 the highest NDVI was observed when seasonal rainfall was in better distribution. While, lower NDVI was observed when amount and distribution of rainfall was minimum (Fig. 5). According to the result the year 2009 and 2015 were considered as drought year in which minimum NDVI was observed and rainfall was registered. While, in the years 2001 and 2007 maximum rainfall and NDVI was observed and considered as wet year (Fig. 5).Normalized Vegetation Index (NDVI)which indicates greens of vegetation has strong relation with seasonal rainfall thus NDVI can be used as an indicator for drought (Gaikwad et al. 2015).

Long term seasonal NDVI values indicts that there is existence of poor vegetation performance distribution in Zone. The central and north western part of Ethiopia which were dominated by crop land had experienced with decreased precipitation and NDVI trend (Liou and Mulualem 2019) There is spatial variation in distribution of vegetation depending on altitude (Fig. 6). In northern part of study area which is lower in elevation good rainfall amount and distribution was observed. However, there is presence of poor vegetation coverage as compared to Southern part of the area. This implies there is presence of other environmental factors which influences growth and development/condition of vegetation. Other local factors like soil characteristics, land use land cover pattern and stress in previous years have an influence on vegetation (Belal et al. 2014). This result indicates in same part of study area rainfall amount and NDVI value were not correlated this is because of presence of other variables like soil, temperature, and topography which, affect growth and development of vegetation. Thus, Rainfall which is an important climate variable that influences the growth and development of vegetation which is reflected by NDVI is not the only factors that influence growth and development of vegetation.

\section{Vegetation condition index $(\mathrm{VCl})$ and agricultural drought} In this study Vegetation Condition Index (VCI) which was derived from NDVI was computed from 2000 to 2016 to analyze severity of agricultural drought. According to Kogan (1995) report VCI is better indicator of water stress condition than NDVI. In this study majority of the area where influenced by drought during drought year of 2009 and 2015. In line with this finding (Gebrehiwot et al. 2016) assert year 2009 were identified as drought year using vegetation condition index in Ethiopia. Drought year of 2015 majority of the area were stricken by very severe drought (Table 4). While, Southern part of study area were not influenced by agricultural drought in 2015 as expressed by VCI, whereas other parts of study area were hit by very severe to slight drought (Fig. 7). This indicated that areas which are low in altitude were sensitive to agricultural drought. Vegetation Condition Index (VCI) below 35\% can be identified as sever and very severe drought condition (Kogan 1997), 

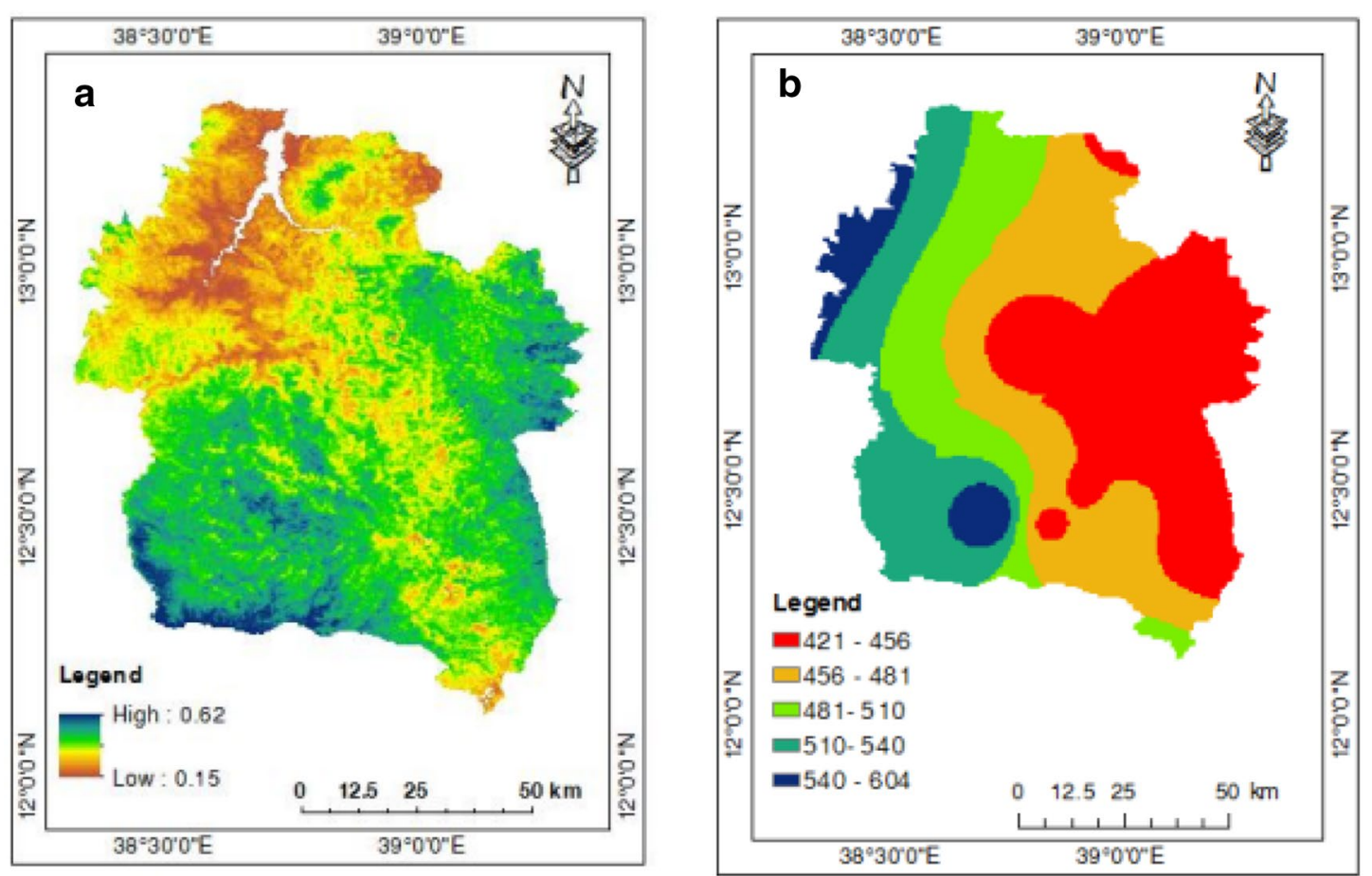

Fig. 6 Spatial pattern of long term seasonal (June to September) NDVI (a) and rainfall (b)

Table 4 Agricultural drought severity for drought year 2009 and 2015 and wet year 2001 and 2007

\begin{tabular}{|c|c|c|c|c|c|}
\hline \multirow[t]{3}{*}{ No. } & \multirow[t]{3}{*}{ Class } & \multicolumn{2}{|c|}{ Drought year } & \multicolumn{2}{|l|}{ Wet year } \\
\hline & & 2009 & 2015 & 2001 & 2007 \\
\hline & & Area (\%) & Area (\%) & Area (\%) & Area (\%) \\
\hline 1 & Very severe drought & 32.2 & 45.6 & 1.1 & 3.8 \\
\hline 2 & Severe drought & 28.3 & 17.4 & 2.2 & 4.1 \\
\hline 3 & Moderate drought & 23.5 & 14.7 & 6.0 & 7.2 \\
\hline 4 & Slight drought & 9.23 & 7.38 & 7.5 & 6.2 \\
\hline \multirow[t]{2}{*}{5} & $\begin{array}{l}\text { Optimal/normal } \\
\text { drought }\end{array}$ & 6.86 & 15 & 83 & 79 \\
\hline & Total & 100 & 100 & 100 & 100 \\
\hline
\end{tabular}

which is found in poor vegetation condition. The results of this study also reveal majority of study area were found under poor vegetation condition during cropping season of those drought years. Generally VCI confirm that in the year 2009 and 2015 almost all part of the study area were affected by agricultural drought condition.

Similarly vegetation condition indexes (VCI) for wet years were computed. As shown drought map (Fig. 8) majority of study area were not under influence of drought in both 2001 and 2007. The value of VCI was above $50 \%$ in most of study area. This indicates the value of VCI was above the average indicting good condition of vegetation during cropping season of those years. This means that there is no vegetation stress due to water shortage. In the year 2001 cropping season the percentage area, which were not hit by agricultural drought accounts to $83 \%$ whereas in $2007,79 \%$ of the total areas were free from drought. However, Very small areas were hit by very severe to slight drought during cropping season of 2001 and 2007 (Table 4) and (Fig. 8).

\section{Relation between $\mathrm{VCl}$ and crop yield anomaly}

To validate the reliability of satellite based agricultural drought indices crop yield data was taken as a ground truth data. The correlation between VCI and crop yield anomaly was positive and it revalued that there is good relation between two variables with $r=0.72$ (Fig. 9). This indicates $52 \%$ of yield variability can be explained by using vegetation condition index. As vegetation condition index increase crop yield can also increase and vise-versa. This implies higher crop yield reduction was observed in year 2009 and 2015 when the value of VCI was lowest. While, highest yield were found in year 2007 and 2001 when the value of VCI was higher (Fig. 10). Thus, this study verifies that VCI can explain existence of agricultural drought in a good and reliable manner. 

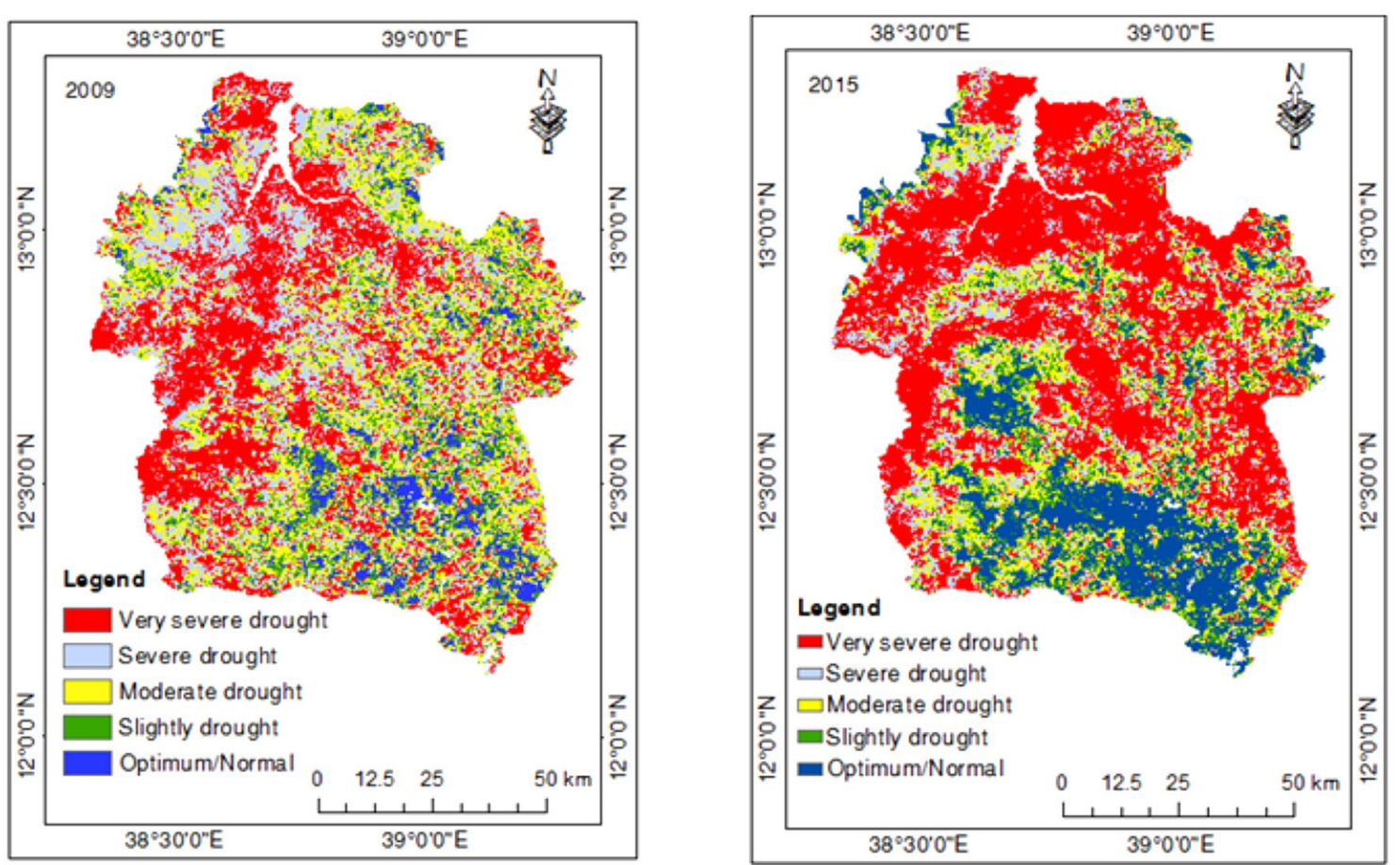

Fig. 7 Spatial pattern of agricultural drought expressed by Vegetation condition index during drought year 2009 and 2015
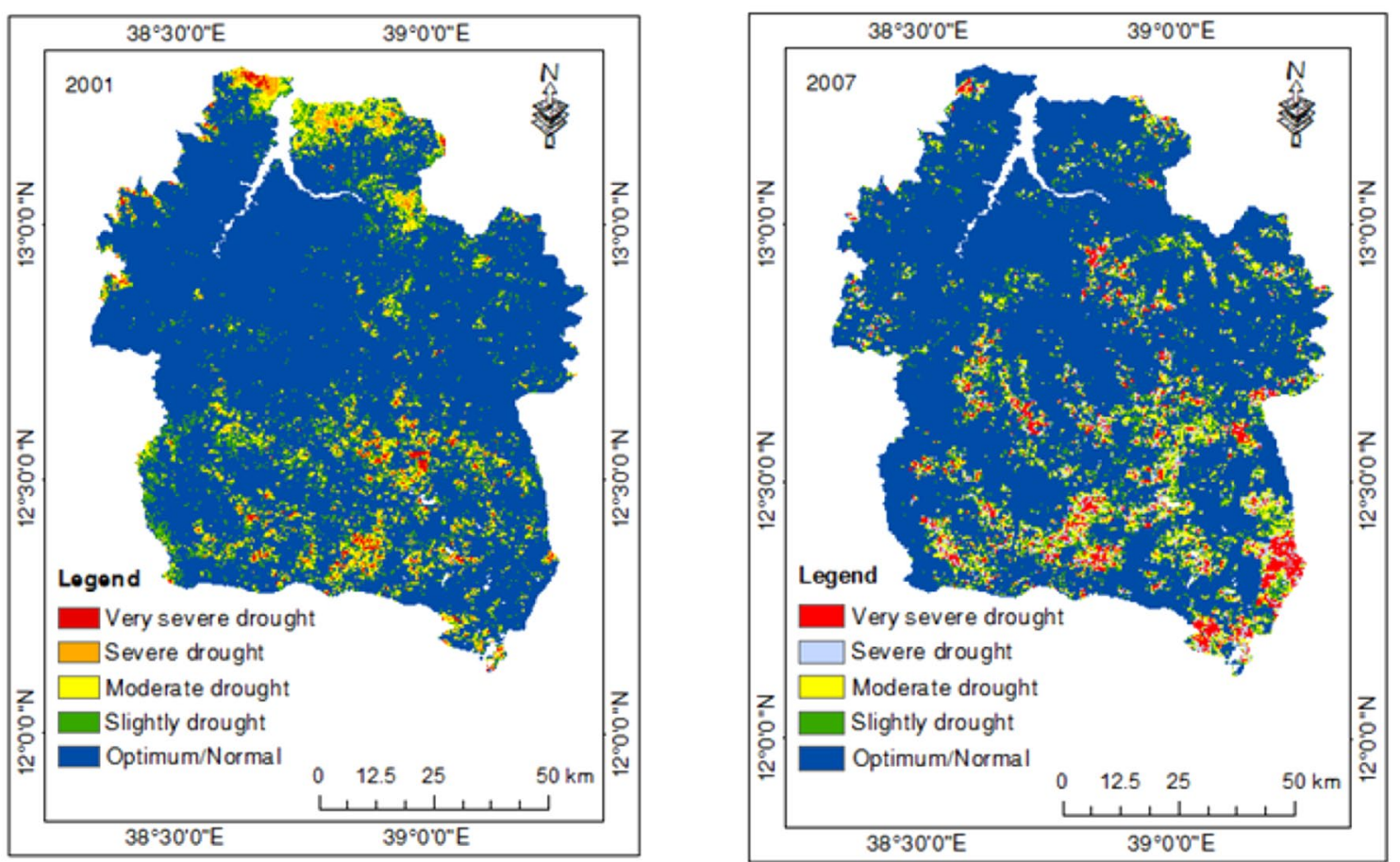

Fig. 8 Spatial pattern of agricultural drought expressed as VCl during wet year 2001 and 2007 


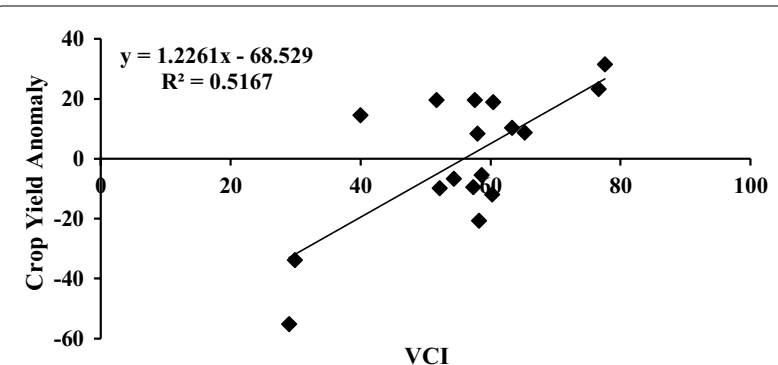

Fig. 9 Relation between $\mathrm{VCl}$ and crop yield anomaly

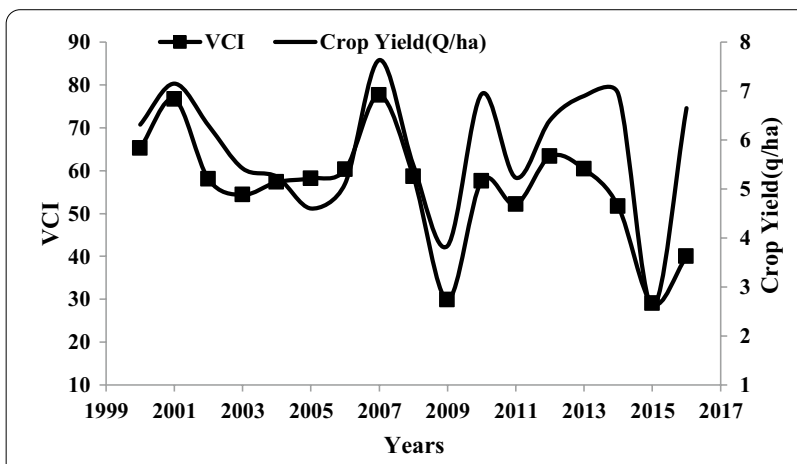

Fig. 10 Temporal trend of $\mathrm{VCl}$ and Crop Yield data (Q/ha)

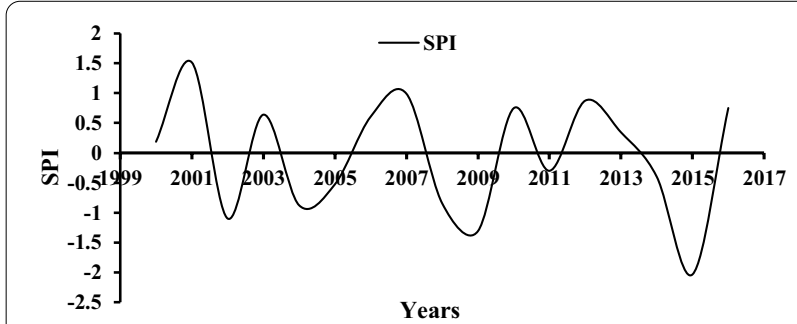

Fig. 11 Temporal trend of Standard Precipitation Index (2000 to 2016)

\section{Meteorological drought characterization based on SPI}

The computed SPI value for 3 months time scale during summer season revealed that occurrence of negative SPI or drought were observed in the year 2003, 2004, 2005, 2008, 2009, 2011, 2014 and 2015 while in other years positive SPI value was observed in study period (Fig. 11). Negative SPI values indicated that the rainfall of the area is less than median rainfall and positive indicate that the rainfall is greater than median rainfall. Every positive SPI value indicates greater than the mean precipitation is wet region and every negative value less than the median across the normal distribution are drier regions (McKee et al. 1993). This finding
Table 5 Metrological drought during 2009 and 2015 as expressed by SPI

\begin{tabular}{llll}
\hline No. & Class & Drought year & \\
\cline { 3 - 4 } & & $\mathbf{2 0 0 9}$ & $\mathbf{2 0 1 5}$ \\
& & Area (\%) & Area (\%) \\
\hline 1 & Very severe drought & 0.2 & 45 \\
2 & Severe drought & 24.5 & 54.5 \\
3 & Moderate drought & 66 & 0.5 \\
4 & Slight drought & 9.3 & - \\
\hline
\end{tabular}

is coinciding with UNOCHA (2015) and FAO (2014) reports as year 2008 documented droughts of Ethiopia which were all strong ElNino years. This indicated that entire study area is considered as metrological drought prone. This finding agree with the finding of Mohammed et al. (2018) who found that North eastern part of Ethiopia is frequently affected by metrological drought using SPI approach. However, the lowest SPI value was observed in 2009 next to 2015 which were considered drought year while the highest SPI was observed in 2007 next to 2001 which were considered as wet year using vegetation indices. This is an agreement with results found through analysis of satellite data through NDVI index and rainfall data from metrological stations found in and around study areas. The drought years identified by SPI analysis in Waghimra Zone are known for their substantial damage in terms of economic loss and life like other parts of Ethiopia which agree with the finding of (Gebrehiwot et al. 2011; Mekonen et al. 2020; Legesse and Suryabhagavan 2014).

This study examined spatial pattern of metrological drought across the study area using time series (2000 to 2016) SPI value. The analysis of SPI revealed that drought has been occurred at different level of severity across study area during the main cropping season. Standard Precipitation Index (SPI) during selected drought years of 2009 and 2015 and wet years of 2001 and 2007 have been presented to show the spatial pattern of SPI during these years. Drought occurred on large spatial extent mainly on summer season of year 2015 and 2009. It can be seen that during the drought year of 2009 and 2015 SPI value was lowest. This indicates that there has been low rainfall in study area during those years. Majority of the area (99.5\%) were stricken by very sever and severe drought in year 2015 (Table 5).In agreement with this finding Mekonen et al. (2020) reported that the year 2015 were the driest year recorded in Kirmet season in north east highland of Ethiopia. Spatial and temporal severity map showed that Eastern part of the study area was highly 

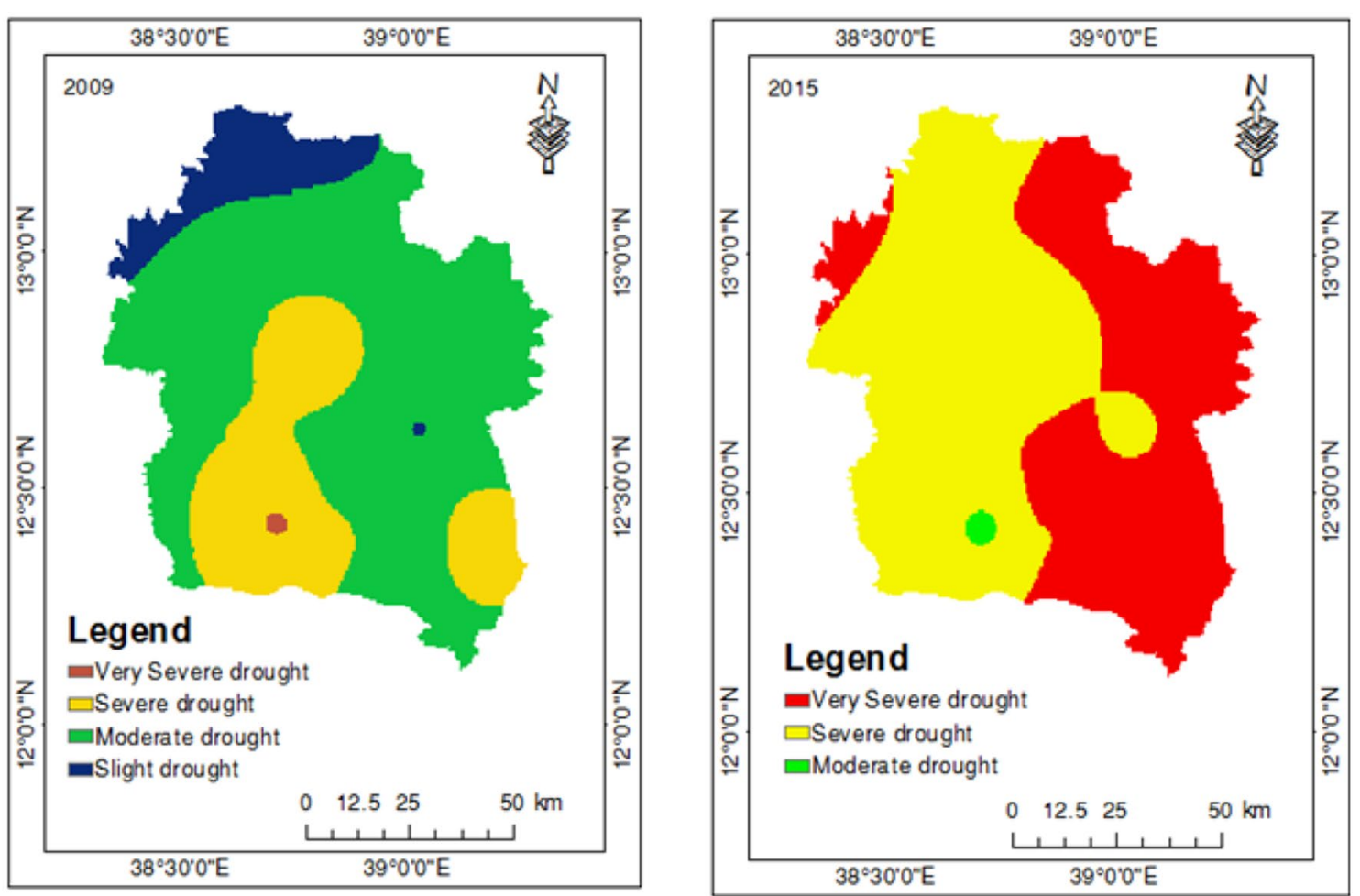

Fig. 12 Standard Precipitation Index for drought year 2009 and 2015
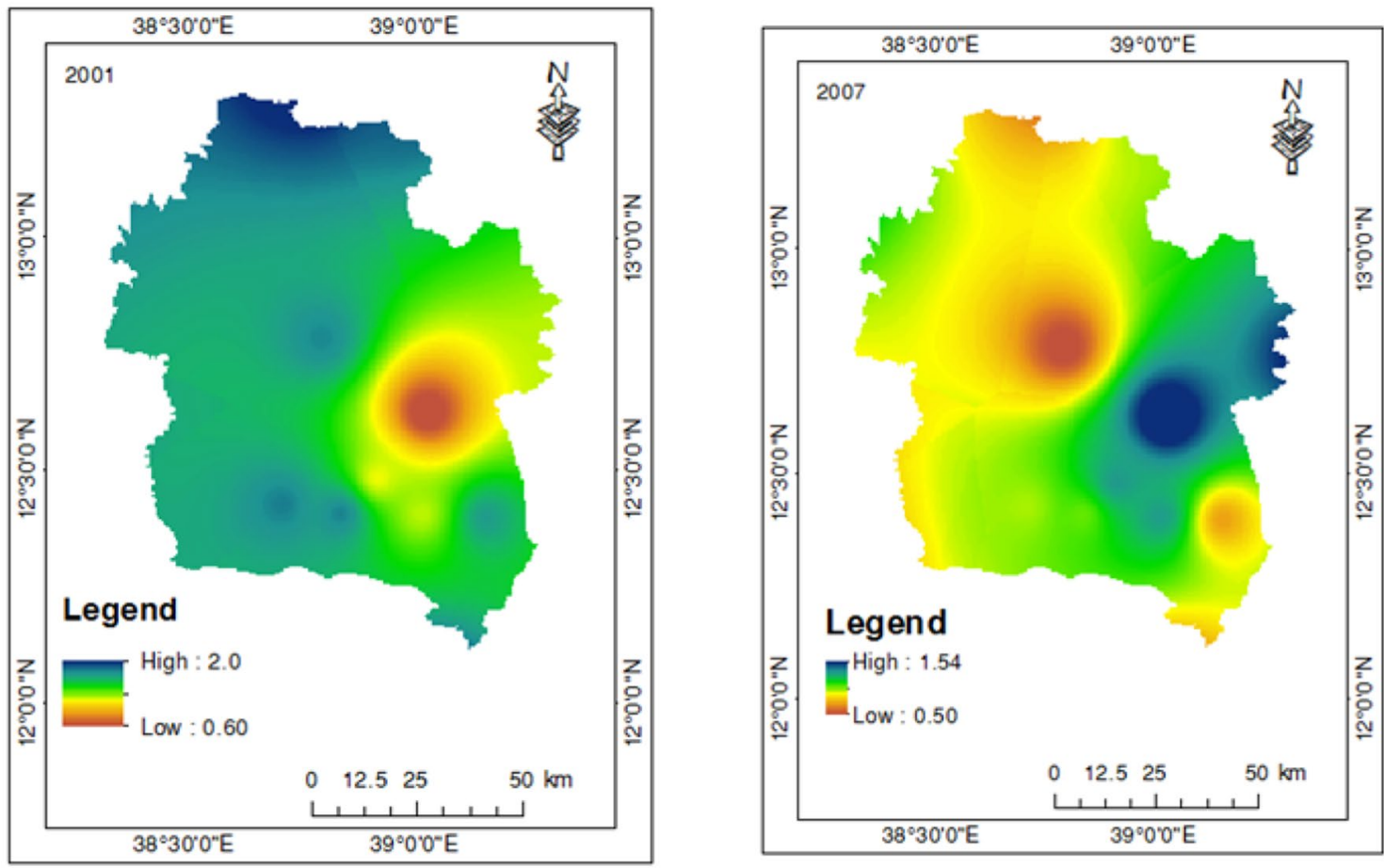

Fig. 13 Standard Precipitation Index for wet year 2001 and 2007 
strike by very severe drought relative to western part which was strike by severe drought. The worst drought of 2015-2016 in northern and central part of Ethiopia because of belg rains had failed and soon after Kiremt rains were severely delayed, erratic and below the long term average (deficit of $167 \mathrm{~mm}$ ) (Jiemba et al. 2017). While, in year the 2009 majority of the study area (66\%) were strike by moderate drought. Northern part of study area was affected by slight drought (Fig. 12). This indicted that there was low rainfall distribution during

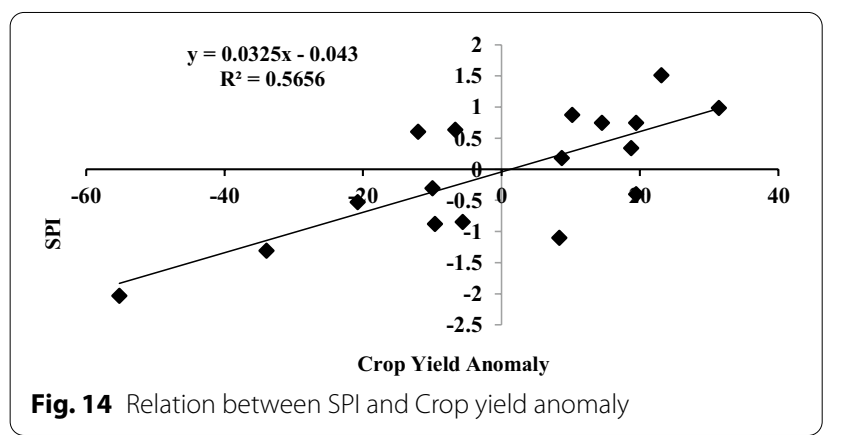

the main crop growing season. Therefore, those years were seen as the worst dry season in study period.

According to analysis spatial pattern of SPI were used to identify wet years. In this regard 2001 and 2007 were identified as wet year in the study area. The highest SPI value which is above zero was observed in those years (Fig. 12). This indicts that there is good distribution of seasonal rainfall. All areas were not under the influence of drought. This implies growing season of 2001 and 2007 were not characterized by water deficit and can be considered as good agricultural time (Fig. 13).

\section{Standard precipitation index (SPI) and crop yield anomaly}

To validate this correlation analysis between SPI and crop yield anomaly was conducted. As shown in (Fig. 14) there is a positive correlation between two variables with $r=0.75$. This implies $56 \%$ of crop yield can be explained by SPI. Thus an overall analysis of this can be summed that SPI can be used as an indicator of metrological drought assessment.

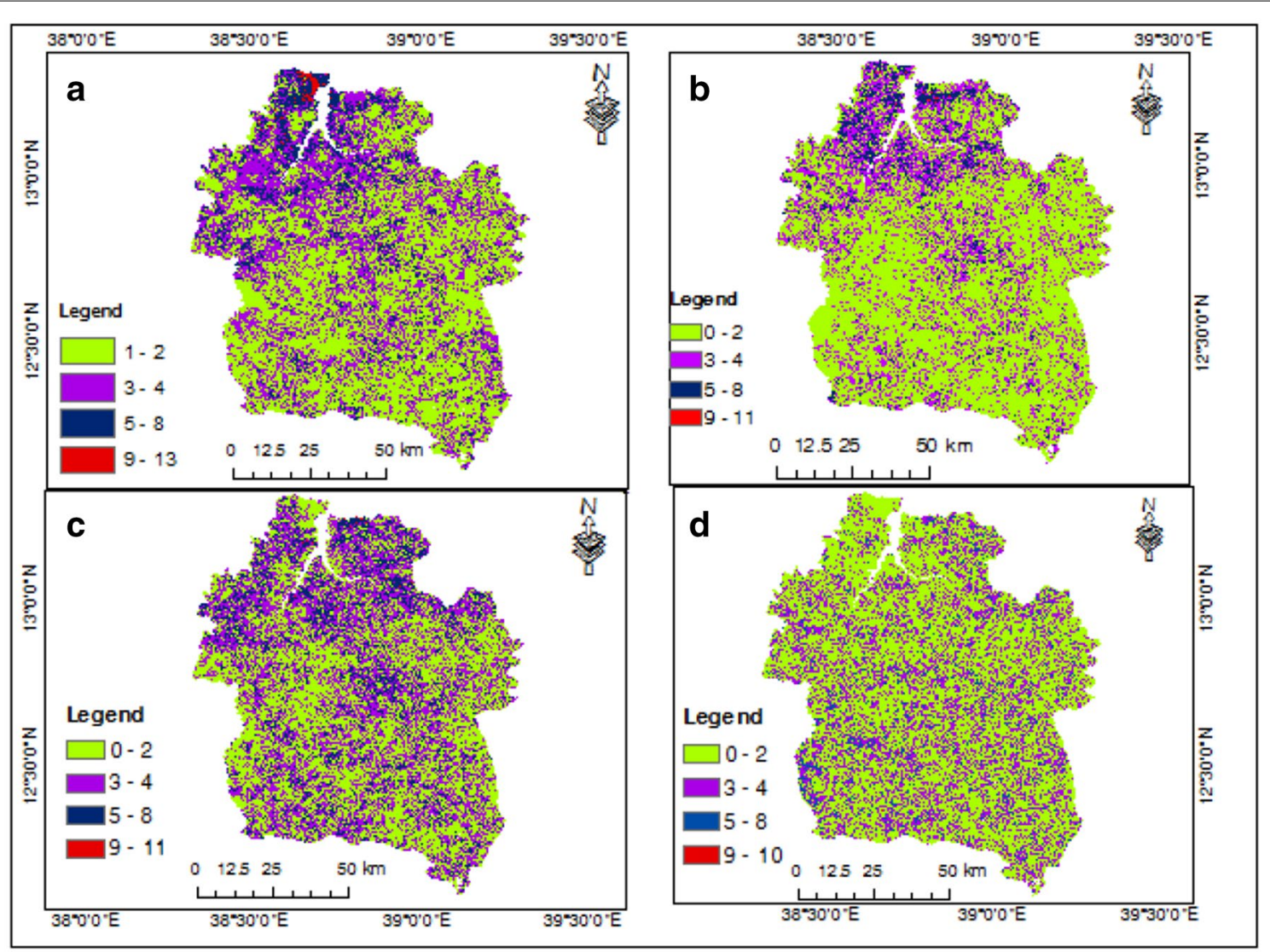

Fig. 15 Frequency of Agricultural drought risk in four different severity classes: a very severe, $\mathbf{b}$ severe, $\mathbf{c}$ moderate and $\mathbf{d}$ slight 


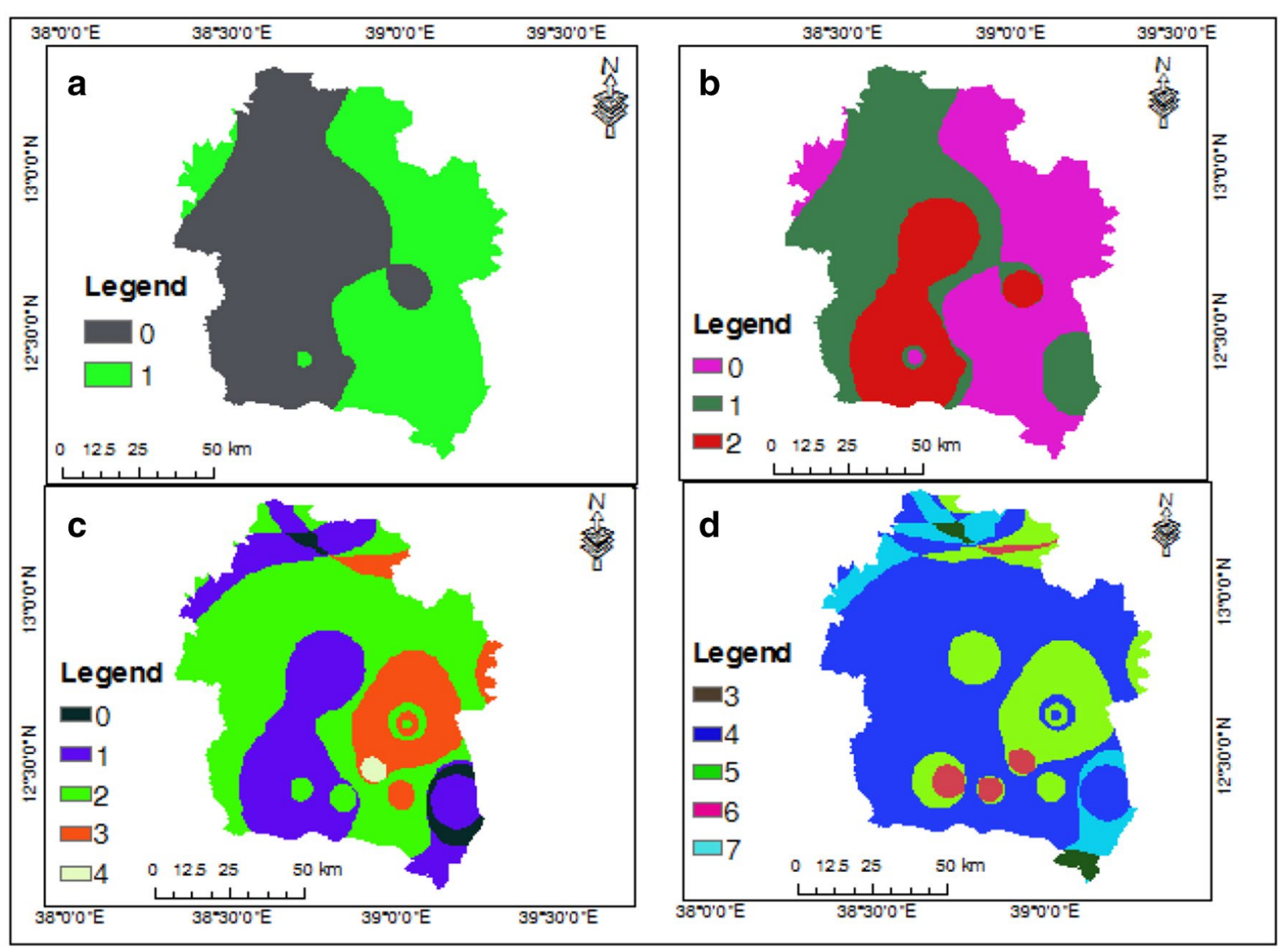

Fig. 16 Frequency (year) of metrological drought risk in four different severity classes: a very severe, $\mathbf{b}$ severe, $\mathbf{c}$ moderate and $\mathbf{d}$ slight

\section{Frequency of drought risk map}

Frequency of meteorological and agricultural drought was compiled by using historical drought intensity map. The result shows that there is complex spatial variation in frequency of drought events in the study area. North part of the study area were frequently affected by very sever agricultural drought (Fig. 15). While southern and central part of the study area were frequently affected by slight to sever agricultural drought condition. This implies that in the study area short return period of agricultural drought was recorded. As shown in (Fig. 18) a combined frequency of agricultural drought almost all areas were highly vulnerable to frequent agricultural drought. Of the total recorded drought years (1953-2016) in Ethiopia, northern part of the country experienced about $72 \%$ of drought events (Little et al. 2006).

Frequency of meteorological drought occurrence resulted in severe drought was occurred in one year which affect southwestern and north western part of the study area. Ethiopia is often stricken by drought in the 1970s and 1980s which resulted in widespread of poverty, economic, stagnation, depletion of household assets, saving and excess mortality (Dorosh and Rashid 2013).
Metrological drought is the main driver leading to the more likely occurrence of agricultural drought. Areas where there is low vegetation cover were prone to agricultural and metrological drought (Fig. 16). This indicates that there is no year without drought in many parts of study area.

\section{Combined drought risk map}

The final drought risk map was prepared by overlaying agricultural and meteorological drought maps (Fig. 17). The weighed was given according to their degree of influence in pair wise comparison in which $55 \%$ was given for agricultural drought. The results reveal that majority of the study area were vulnerable with severe drought which covers around $56 \%$ of total geographical area which is dominated in northern part of the study area. In addition central parts of the study area were vulnerable to moderate drought which covers $35 \%$ of total geographical area. Small portion of the study area was affected by slight and very severe drought, which encompasses 0.4 and $8.3 \%$ of the study area respectively (Table 6 and Fig. 18). Similarly Bayissa et al. (2015) 

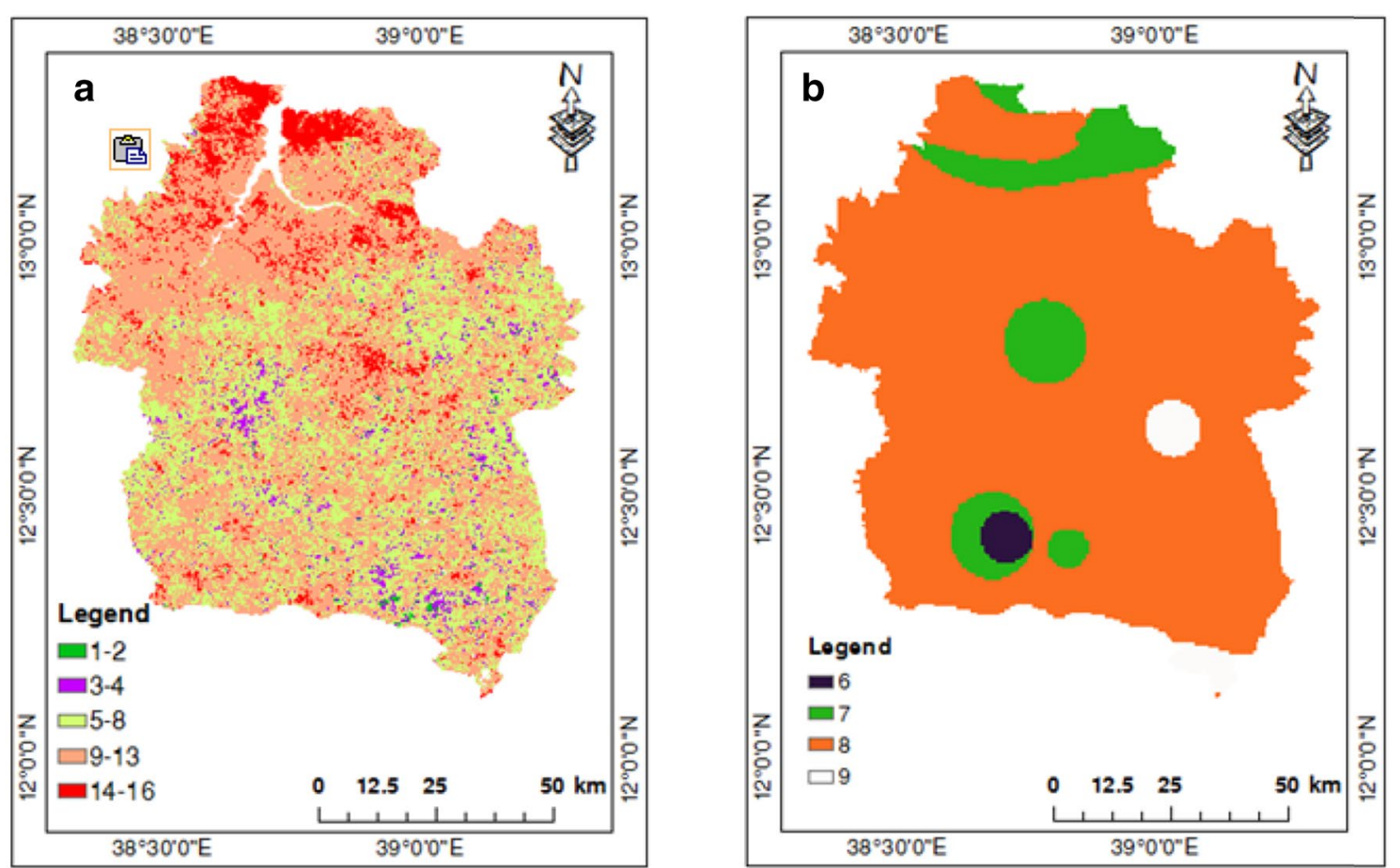

Fig. 17 Frequency of agricultural (a) and metrological (b) drought risk map

Table 6 Area under drought severity class

\begin{tabular}{ll}
\hline Drought severity class & Area (\%) \\
\hline Slight & 0.4 \\
Moderate & 35 \\
Severe & 56 \\
Very severe & 8.3 \\
Total & 100 \\
\hline
\end{tabular}

reported that large parts of Tigray Zones are prone for drought events which are proximate to study area.

As confirmed from informal interviews of zonal agricultural experts Waghimra Zone is known for prolong and recurring drought features, this study also agree with this fact that the area experienced successive drought events during the last 17 years.

\section{Conclusions}

The present study revealed that drought can be delineated by remote sensing indices like vegetation condition index derived from vegetation data and standard precipitation index derived from monthly rainfall data. This study concluded that spatial and temporal variation of NDVI is closely linked with precipitation data and there is strong relation during crop growing period.

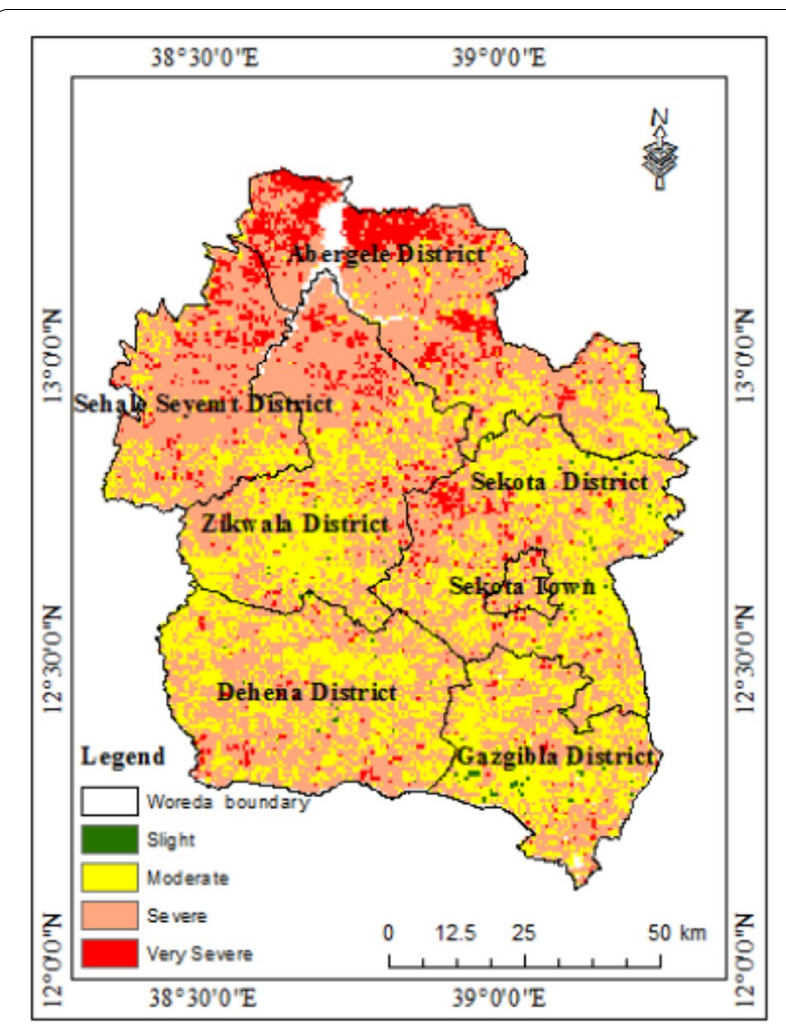

Fig. 18 Combined Drought risk map of study area 
In addition good correlation was observed between VCI and crop yield anomaly, SPI and crop yield anomaly. The result reveals that from the year 2000 to 2016 Waghimra zone experiences sever and slightly severe drought. The Year 2009 has been found to be the year of the worst drought next to 2015 while in the year 2001 and 2007 the area were wet year which shows good crop yield. In Waghimra Zone there is spatial variation in frequency of drought events. According to the result, northern part of the study area were frequently affected by very sever agricultural drought while southern and central part of the study area were affected by sever to slight drought condition. Combined drought risk map showed that $8 \%, 56 \%$ and, $35 \%$ of study area were vulnerable to very severe, severe and moderate drought condition respectively. This revealed that study area is frequently vulnerable to agricultural and meteorological drought. Therefore, using geospatial data to assess agricultural drought is a paramount importance in order to assess past and current drought condition which generate baseline information that helps to monitor real time situation in the future for different adaptation options within relatively large geographical area coverage and repetitively time scale.

\begin{abstract}
Abbreviations
eMODIS: Enhanced/expedited/expandable MODIS data; EROS: Earth resource observation and science; GIS: Geographic information system; GPS: Global positioning system; IDW: Inverse distance weight; LULC: Land use land cover; MODIS: Moderate resolution imaging spectro-radiometer; NDVI: Normalized difference vegetation index; NIR: Near infrared band; SPI: Standard precipitation index; USGS: United States Geological Survey; UTM: Universal transverse mercator; $\mathrm{VCl}$ : Vegetation condition index; VHI: Vegetation health index; WGS: World geodetic system.
\end{abstract}

\section{Acknowledgements}

We are grate full to Ethiopia national metrological station agency and Ethiopian central statistics agency for providing us monthly rainfall and crop yield data respectively. Waghimra Zone community also deserves appreciation for their kind response to any requested information.

\section{Authors' contributions}

The research idea was conceived by AS. He actively participated in the design of the study, carried out the data collection, and undertook the GIS and Remote sensing-based data analysis. More importantly, he conducted the full write-up of the research report and organized the manuscript for publication. SA and KVS read edit and approve the manuscript for publication.

\section{Funding}

Not applicable.

\section{Availability of data and materials}

The dataset and material used during analysis area available from the first author on reasonable request.

\section{Ethics approval and consent to participate}

Not applicable.

\section{Consent for publication}

Not applicable.

\section{Competing interest}

Authors declares that they have no competing interests.

\section{Author details}

${ }^{1}$ College of Agriculture and Environmental Sciences, Bahir Dar University, P.o.box 5501 Bahir Dar, Ethiopia. ${ }^{2}$ College of Natural Sciences, Addis Ababa University, P.o.box 1188 Addis Ababa, Ethiopia.

Received: 3 September 2020 Accepted: 22 November 2020

Published online: 09 February 2021

\section{References}

Ahmadalipour A, Moradkhani H (2018) Multi-dimensional assessment of drought vulnerability in Africa: 1960-2100. Sci Total Environ. https://doi. org/10.1016/j.scitotenv.2018.07.023

Araya A, Stroosnijder L (2011) Assessing drought risk and irrigation need in northern Ethiopia. Agric For Meteorol. https://doi.org/10.1016/j.agrfo rmet.2010.11.014

Bayissa Y, Tadesse T, Demisse G, Shiferaw A (2017) Evaluation of satellite-based rainfall estimates and application to monitor meteorological drought for the Upper Blue Nile Basin, Ethiopia. Remote Sensing. https://doi. org/10.3390/rs 9070669

Bayissa Y, Moges SA, Xuan Y, Van Andel J, Maskey S, Solomatine D, Griensven V, Tadesse T (2015) Spatio-temporal assessment of meteorological drought under the influence of varying record length: The case of upper Blue Nile basin. Ethiopia. Hydro sci J. https://doi.org/10.1080/02626667.2015

Belal AA, El-Ramady HR, Mohamed ES, Saleh AM (2014) Drought risk assessment using remote sensing and GIS techniques. Arab J Geosci. https:// doi.org/10.1007/s12517-012-0707-2

Berhanu T (2015) Project on air pollution in the context of Ethiopia based on Kaizen philosophy Forwarded Message, pp 1-51

Bhuiyan C, Singh RP, Kogan FN (2006) Monitoring drought dynamics in the Aravalli region (India) using different indices based on ground and remote sensing data. Int J Appl Earth Obs Geoinf. https://doi. org/10.1016/j.jag.2006.03.002

Demisse GB, Tadesse T, Bayissa Y, Atnafu S, Argaw M, Nedaw D (2018) Vegetation condition prediction for drought monitoring in pastoralist areas: a case study in Ethiopia. Int J Remote Sens. https://doi.org/10.1080/01431 161.2017.1421797

Ding Y, Hayes MJ, Widhalm M (2011) Measuring economic impacts of drought: a review and discussion. Disaster Prev Manag. https://doi. org/10.1108/09653561111161752

Dorosh P, Rashid S (2013) Food and Agriculture in Ethiopia: progress and police challenges. Int J the Commons. 7 (2):573-574, https://doi. org/10.18352/ijc.448

Edossa DC, Babel MS, Gupta AD (2010) Drought analysis in the Awash River Basin, Ethiopia. Water Resour Manag. https://doi.org/10.1007/s1126 9-009-9508-0

Food and Agriculture Organization of the United Nations (2006) Food Security and Protracted Crisis, Policy Brief.

Food and Agriculture Organization of the United Nations (2014) Understanding the drought impact of El Niño on the global agricultural areas: an assessment using FAO's Agricultural Stress Index (ASI), ISBN 978-92-5-108671-1

Gaikwad SV, Kale KV, Kulkarni SB, Varpe AB, Pathare GN (2015) Agricultural drought severity assessment using remotely sensed data: a review. Int J Adv Remote Sens GIS. https://doi.org/10.23953/cloud.ijarsg.128

Gebrehiwot T, van der Veen A, Maathuis B (2011) Spatial and temporal assessment of drought in the Northern highlands of Ethiopia. Int J Appl Earth Obs Geoinf. https://doi.org/10.1016/j.jag.2010.12.002

Gebrehiwot T, Van der Veen A, Maathuis B (2016) Governing agricultural drought: monitoring using the vegetation condition index. Ethiop J Environ Stud Manag. https://doi.org/10.4314/ejesm.v9i3.9

Gordon ND, McMahon TA, Finlayson BL (1992) Stream hydrology: an introduction for ecologists. Stream Hydrol an Introd Ecol. https://doi. org/10.1016/0925-8574(93)90041-d 
Guo H, Zhang X, Lian F, Gao Y, Lin D, Wang J (2016) Drought risk assessment based on vulnerability surfaces: a case study of maize. Sustain. https://doi. org/10.3390/su8080813

Guttman NB (1998) Comparing the palmer drought index and the standardized precipitation index. J Am Water Resour Assoc. https://doi. org/10.1111/j.1752-1688.1998.tb05964.x

Hassan A (2008) Vulnerability to drought risk and famine: local responses and external interventions among the afar of Ethiopia: a study on the Aghini pastoral community. Univ Bayreuth, Bayreuth

Hayes M, Svoboda M, Wall N, Widhalm M (2011) The lincoln declaration on drought indices: Universal meteorological drought index recommended. Bull Am Meteorol Soc. https://doi.org/10.1175/2010BAMS31 03.1

Jayanthi H, Husak GJ, Funk C, Magadzire T, Chavula A, Verdin JP (2013) Modeling rain-fed maize vulnerability to droughts using the standardized precipitation index from satellite estimated rainfall-Southern Malawi case study. Int J Disaster Risk Reduct. https://doi.org/10.1016/j.ijdrr.2013.02.001

Jiemba E, Singh R, Arrighi J (2017) Extreme drought in Ethiopia stretches drought management systems

Kalantari Z, Ferreira CSS, Keesstra S, Destouni G (2018) Nature-based solutions for flood-drought risk mitigation in vulnerable urbanizing parts of East-Africa. Curr Opin Environ Sci Health. https://doi.org/10.1016/j.coesh .2018 .06 .003

El Kenawy AM, McCabe MF, Vicente-Serrano SM, López-Moreno Jl, Robaa SM (2016) Cambios en la frecuencia y severidad en las sequías hidrológicas de Etiopía entre 1960 y 2013. Cuad Investig Geogr 42:145-166. https:// doi.org/10.18172/cig.2931

Kogan FN (1995) Droughts of the late 1980s in the United States as derived from NOAA polar-orbiting satellite data. Bull Am Meteorol Soc. https:// doi.org/10.1175/1520-0477(1995)076\%3c0655:DOTLIT\%3e2.0.CO;2

Kogan FN (1997) Global drought watch from space. Bull Am Meteorol Soc. https://doi.org/10.1175/1520-0477(1997)078\%3c0621:GDWFS \%3e2.0.CO;2

Lemma G (1996) Climate classification of Ethiopia. Meteorological Research Report Series No.3. Addis Ababa, Ethiopia, pp 1-8

Legesse G, Suryabhagavan KV (2014) Remote sensing and GIS based agricultural drought assessment in East Shewa, Ethiopia. Trop Ecol 55:349-363

Liou YA, Mulualem GM (2019) Spatio-temporal assessment of drought in Ethiopia and the impact of recent intense droughts. Remote Sens. https://doi. org/10.3390/rs11151828

Liu WT, Kogan FN (1996) Monitoring regional drought using the vegetation condition index. Int J Remote Sens. https://doi.org/10.1080/0143116960 8949106

Liu W, Sun F, Ho Lim W, Zhang J, Wang H, Shiogama H, Zhang Y (2018) Global drought and severe drought-affected populations in 1.5 and 2 deg $C$ warmer worlds. Earth Syst Dyn. https://doi.org/10.5194/esd-9-267-2018

Van Loon AF (2015) Hydrological drought explained. Wiley Interdiscipl Rev Water. https://doi.org/10.1002/wat2.1085

Van Loon AF, Laaha G (2015) Hydrological drought severity explained by climate and catchment characteristics. J Hydrol. https://doi.org/10.1016/j. jhydrol.2014.10.059

Little PD, Stone MP, Mogues T, Castro AP, Negatu W (2006) Moving in places: drought and poverty dynamics in south wollo. Ethiopia. J Dev Stud 42(2):200-2025. https://doi.org/10.1080/00220380500405287

Maybank J, Bonsai B, Jones K, Lawford R, O'Brien EG, Ripley EA, Wheaton E (1995) Drought as a natural disaster. Atmos Ocean. https://doi. org/10.1080/07055900.1995.9649532

McKee TB, Nolan J, Kleist J (1993) The relationship of drought frequency and duration to time scales. In: Proceedings of the 8th conference on applied climatology

Mekonen AA, Berlie AB, Ferede MB (2020) Spatial and temporal drought incidence analysis in the northeastern highlands of Ethiopia. Geoenviron Disasters. https://doi.org/10.1186/s40677-020-0146-4

Meza I, Siebert S, Döll P, Kusche J, Herbert C, Rezaei EE, Nouri H, Gerdener H, Popat E, Frischen J, Naumann G, Vogt JV, Walz Y, Sebesvari Z, Hagenlocher M (2020) Global-scale drought risk assessment for agricultural systems. Nat Hazards Earth Syst Sci. https://doi.org/10.5194/nhess $-20-695-2020$

Misra AK (2014) Climate change and challenges of water and food security. Int J Sustain Built Environ. https://doi.org/10.1016/j.ijsbe.2014.04.006
Moges SA, Gebregiorgis AS (2013) Climate vulnerability on the water resources systems and potential adaptation approaches in East Africa: the case of Ethiopia. In: Climate vulnerability: understanding and addressing threats to essential resources. doi: https://doi.org/10.1016/B978-0-12-38470 3-4.00517-7.

Mohammed Y, Yimer F, Tadesse M, Tesfaye K (2018) Meteorological drought assessment in north east highlands of Ethiopia. Int J Clim Chang Strateg Manag. https://doi.org/10.1108/IJCCSM-12-2016-0179

Morid S, Smakhtin V, Moghaddasi M (2006) Comparison of seven meteorological indices for drought monitoring in Iran. Int J Climatol 26(7):971-985. https://doi.org/10.1002/joc.1264

Paulo AA, Rosa RD, Pereira LS (2012) Climate trends and behaviour of drought indices based on precipitation and evapotranspiration in Portugal. Nat Hazards Earth Syst Sci. https://doi.org/10.5194/nhess-12-1481-2012

Prenzel B (2004) Remote sensing-based quantification of land-cover and land-use change for planning. Prog Plann. https://doi.org/10.1016/S0305 $-9006(03) 00065-5$

Pulwarty RS, Sivakumar MVK (2014) Information systems in a changing climate: early warnings and drought risk management. Weather Clim Extrem. https://doi.org/10.1016/.wace.2014.03.005

Quiring SM, Papakryiakou TN (2003) An evaluation of agricultural drought indices for the Canadian prairies. Agric For Meteorol. https://doi.org/10.1016/ S0168-1923(03)00072-8

Rojas O, Vrieling A, Rembold F (2011) Assessing drought probability for agricultural areas in Africa with coarse resolution remote sensing imagery. Remote Sens Environ. https://doi.org/10.1016/j.rse.2010.09.006

Shahid S, Behrawan H (2008) Drought risk assessment in the western part of Bangladesh. Nat Hazards. https://doi.org/10.1007/s1 1069-007-9191-5

Tadesse T (2018) Strategic framework for drought risk management and enhancing resilience in Africa. University of Nebraska-Lincoln, Nebraska

Tadesse T, Demisse GB, Zaitchik B, Dinku T (2014) Satellite-based hybrid drought monitoring tool for prediction of vegetation condition in Eastern Africa: a case study for Ethiopia. Water Resour Res. https://doi. org/10.1002/2013WR014281

Taylor RG, Scanlon B, Döll P, Rodell M, Van Beek R, Wada Y, Longuevergne L, Leblanc M, Famiglietti JS, Edmunds M, Konikow L, Green TR, Chen J, Taniguchi M, Bierkens MFP, Macdonald A, Fan Y, Maxwell RM, Yechieli Y, Gurdak JJ, Allen DM, Shamsudduha M, Hiscock K, Yeh PJF, Holman I, Treidel H (2013) Ground water and climate change. Nat Clim Chang. https ://doi.org/10.1038/nclimate1744

Tesfaye K, Walker S (2004) Matching of crop and environment for optimal water use: the case of Ethiopia. Phys Chem Earth. https://doi. org/10.1016/j.pce.2004.09.024

Thenkabail PS, Gamage MSDN, Smakhtin VU (2004) The use of remote sensing data for drought assessment and monitoring in southwest Asia. IWMI Res Rep. https://doi.org/10.3910/2009.086

Trenberth KE, Dai A, Van Der Schrier G, Jones PD, Barichivich J, Briffa KR, Sheffield J (2014) Global warming and changes in drought. Nat Clim Chang. https://doi.org/10.1038/nclimate2067

Tsakiris G (2017) Drought risk assessment and management. Water Resour Manag. https://doi.org/10.1007/s11269-017-1698-2

Tsakiris G, Pangalou D, Vangelis H (2007) Regional drought assessment based on the Reconnaissance Drought Index (RDI). Water Resour Manag. https ://doi.org/10.1007/s11269-006-9105-4

Turral H, Burke J, Faures JM (2011) Climate change, water and food security: Rome Food Agric Organ United Nations.

Vicente-Serrano SM, Beguería S, Lorenzo-Lacruz J, Camarero JJ, López-Moreno Jl, Azorin-Molina C, Revuelto J, Morán-Tejeda E, Sanchez-Lorenzo A (2012) Performance of drought indices for ecological, agricultural, and hydrological applications. Earth Interact. https://doi.org/10.1175/2012E I000434.1

Viste E, Korecha D, Sorteberg A (2013) Recent drought and precipitation tendencies in Ethiopia. Theor Appl Climatol. https://doi.org/10.1007/ s00704-012-0746-3

Wattanakij N, Thavorntam W, Mongkolsawat C (2006) Analyzing Spatial Pattern of Drought in the Northeast of Thailand using multi-temporal Standardized Precipitation index (SPI). In: Asian Association on Remote Sensing27th Asian Conference on Remote Sensing, ACRS

Wheeler T, Von Braun J (2013) Climate change impacts on global food security. Science. https://doi.org/10.1126/science.1239402 
Wilhite DA, Sivakumar MVK, Pulwarty R (2014) Managing drought risk in a changing climate: the role of national drought policy. Weather Clim Extrem 3:4-13. https://doi.org/10.1016/j.wace.2014.01.002

Wilhite DA, Svoboda MD, Hayes MJ (2007) Understanding the complex impacts of drought: a key to enhancing drought mitigation and preparednes. Water Resour Manag. https://doi.org/10.1007/s11269-006-9076-5

Wilhite DA, Buchanan-Smith M (2005) Drought as hazard: Understanding the natural and social context. In: Drought and water crises: science, technology, and management issues. doi: https://doi.org/10.1201/b22009-2

Winkler K, Gessner U, Hochschild V (2017) Identifying droughts affecting agriculture in Africa based on remote sensing time series between 2000-2016: rainfall anomalies and vegetation condition in the context of ENSO. Remote Sens. https://doi.org/10.3390/rs9080831

Zarafshani K, Sharafi L, Azadi H, Van Passel S (2016) Vulnerability assessment models to drought: toward a conceptual framework. Sustain. https://doi. org/10.3390/su8060588
Zhu J, Miller A E, Lindsay C, Broderson D, Heinrichs T, Martyn P (2013) Modis Ndvi Products and Metrics

Zhumanova M, Mönnig C, Hergarten C, Darr D, Wrage-Mönnig N (2018) Assessment of vegetation degradation in mountainous pastures of the Western Tien-Shan, Kyrgyzstan, using eMODIS NDVI. Ecol Indic. https:// doi.org/10.1016/j.ecolind.2018.07.060

Zwane EM (2019) Impact of climate change on primary agriculture, water sources and food security in Western Cape, South Africa. Jàmbá J Disaster Risk Stud. https://doi.org/10.4102/jamba.v11i1.562

\section{Publisher's Note}

Springer Nature remains neutral with regard to jurisdictional claims in published maps and institutional affiliations.

\section{Submit your manuscript to a SpringerOpen ${ }^{\circ}$ journal and benefit from:}

- Convenient online submission

- Rigorous peer review

- Open access: articles freely available online

- High visibility within the field

- Retaining the copyright to your article

Submit your next manuscript at $\boldsymbol{\nabla}$ springeropen.com 